\section{Australian Journal of \\ Crop Science}

\title{
Short-term green manure effects on crambe yield and oil content
}

\author{
Doglas Bassegio $^{1 *}$, Reginaldo Ferreira Santos ${ }^{2}$, Marcos Vinícius Mansano Sarto ${ }^{1}$, Chaiane Bassegio ${ }^{3}$, \\ Patricia Pereira Dias ${ }^{1}$, Jéssyca Dellinhares Lopes Martins ${ }^{1}$, Michely da Silva Alves ${ }^{1}$
}

\author{
${ }^{1}$ Faculdade de Ciências Agronômicas, Departamento de Produção e Melhoramento Vegetal, UNESP, CEP 18603- \\ 970, Botucatu, SP, Brazil \\ ${ }^{2}$ Universidade Estadual do Oeste do Paraná, UNIOESTE, Rua Universitária, 2069, CEP 5814-110, Cascavel, PR, \\ Brazil \\ ${ }^{3}$ Pontifícia Universidade Católica do Paraná, PUC, Campus Toledo, CEP 859000-001, Toledo, PR, Brazil
}

*Corresponding author: doglasbassegio@gmail.com

\begin{abstract}
Crambe (Crambe abyssinica Hochst. ex R.E. Fries) is an oilseed crop that can be cultivated in tropical conditions and used for the production of industrial oil. While crambe is believed to be a suitable crop for no-tillage systems, identification of appropriate crop species to precede it is necessary to improve its grain yield and oil content. In this study, we aimed to assess the short-term effects of crop rotation on the grain yield and oil content of a crambe crop cultivated after spring-summer cover crops. The experiment was conducted on an Rhodic Hapludox soil in Santa Helena-PR, Brazil. The experimental design consisted of randomized blocks with four replications. The plots consisted of pearl millet (Pennisetum glaucum), grass brachiaria (Brachiaria brizantha), sorghum (Sorghum bicolor), sunn hemp (Crotalaria juncea) and a fallow area (spontaneous vegetation). Grain yield, oil content, and oil yield were measured. Crambe oil content was influenced by the cover crops. The use of crotalaria as predecessor species resulted in higher oil content, but the result did not differ from that observed in the fallow area. However, grain yield and oil content were benefited by the crotalaria cover crop in the short-term. Crambe looks promising as an alternative oilseed crop for South Brazil when seeded in autumn with crotalaria cover crop in Rhodic Hapludox.
\end{abstract}

Keywords: Crambe abyssinica, Crotalaria juncea, Pennisetum glaucum, Brachiaria brizantha, Sorghum bicolor. Abbreviations: FMS_Foundation Mato Grosso do Sul.

\section{Introduction}

Crambe (Crambe abyssinica Hochst. ex R.E. Fries) is a type of Brassica oilseed, which are the main sources of vegetable oil in semi-arid regions (Premi et al., 2013). As there is a need for plants with industrial potential, this species may be an alternative for cultivation in tropical regions, since it can be grown in rotation in idle areas with autumn-winter crops (Cattanêo et al., 2016). However, in no-tillage systems, owing to the residues left by antecedent species and subsequent utilization, it is necessary to investigate how crambe behaves under crop rotation. Studies have reported that Brassicas show lower yield when cultivated after grasses than when cultivated after legumes (Rathke et al., 2005). Legumes have the ability to fix atmospheric nitrogen and add it to the soil, and thus contribute to the nutrition of the subsequent crop because of nutrient cycling (Elfstrand et al., 2007; Werncke et al., 2014; Bassegio et al., 2015a) and the rapid release of $\mathrm{N}$ in the short term, which improves fertility (Astier et al., 2006). Furthermore, grasses have a high dry matter production potential (Crusciol et al., 2014), and their high C: $\mathrm{N}$ ratio slows down decomposition and increases the possibility of their use in warmer regions, especially in tropical regions. This process thus helps to prevent $\mathrm{N}$ loss via its persistence in soil and by absorption and immobilization of nutrients in the biomass. Crambe as a rotational crop has the ability to recycle and take advantage of residual nutrients from the preceding crop (Pitol, 2008). In Brazil, for example, crambe has been shown to respond favorably from residual fertilization of preceding soybeans (Bitencourt et al., 2016). In this regard, an ongoing process of soil nutrient recycling essentially transfers nutrients from waste predecessor species to newly planted crops (Lunelli et al., 2014). Given this evidence, it is important to examine the need for fertilization and the possible increase in fertilization in preceding crops to increase productivity in the crambe crop (Bitencourt et al., 2015). Several studies have been conducted on crop rotations between legumes and Brassica oilseeds such as mustard, rapeseed, and canola (Aulakh and Pasricha, 1998; Christen, 2001; Mohammadi and Rokhzadi, 2012); however, little is known about the use of the residues left by cover crops in rotations involving crambe as the main crop. Thus, in light of the limited scientific information and with the hypothesis that crop rotation with legumes can benefit crambe, in the present study, we aimed to assess the grain yield and oil content of a crambe crop after cultivation with short-term cover crops.

Results and discussion

\section{Climatic conditions}

Crambe cultivation with cover crops was affected by weather conditions (Figure 1). There was a larger volume of rainfall at the growth and flowering stages $(472 \mathrm{~mm})$ than at the 
formation and grain filling stages $(62 \mathrm{~mm})$. Moreover, temperatures below $0^{\circ} \mathrm{C}$ caused frost, and crambe is sensitive to low temperatures in certain phases (Pitol, 2008).

\section{Grain yield}

However, despite that damage to the crop due to the stress, crambe grain yield (Figure 2A) under crotalaria cover crops was within the expected yield potential (1000-1500 kg ha-1) and it was similar to the results of by Viana et al. (2015). The highest grain yield under crotalaria cover crops was due to short-term intake of nutrients by this species, especially $\mathrm{N}$, which resulted in better crop nutrition, because $\mathrm{N}$ is the most exported nutrient in the harvesting of crambe grains (Mauad et al., 2013); it was also due to the contribution to improvement of the physical conditions of the soil (MunozCarpena et al., 2008). These results are similar to those reported by Tomassoni et al. (2014), who observed shortterm positive effects of crotalaria as a predecessor cover crop on nitrogen fertilization in crambe cultivation. Aulakh and Pasricha (1998), throughout four years of cultivation, observed that cowpea beans used as green manure in the absence of nitrogen fertilization increased Brassica juncea yield. Although other cover crops can accumulate dry matter and nutrients in tropical regions with warm weather, in the short term, the high nutrient release by crotalaria (mainly residual N) leads to higher grain yield, as reported previously (Balkcom and Reeves, 2005; Cherr et al., 2006; Schomberg et al., 2007).

\section{Oil content}

With respect to oil content (Figure 2B), the main determinant of crambe grains, we observed that among all cover crops, crotalaria provided the highest content $(27 \%)$, but this result did not differ from that observed in the fallow areas (25\%). According to Rathke et al. (2006), optimizing oil content involves balancing the synthesis of protein and crude oil in the grains, as well as energy and carbon dioxide $\left(\mathrm{CO}_{2}\right)$, as the management of $\mathrm{N}$ may affect oil synthesis.

Although low oil content was related to low grain yield, as was also observed by Santos et al. (2013) on crotalaria straw, in the short term, crotalaria led to satisfactory results; however, there are reports that high amounts of $\mathrm{N}$ do not influence or cause reduction in oil content in Brassica oilseeds (Hocking et al., 1997; Cheema et al., 2001; Grant et al., 2011). Mohammadi and Rokhzadi (2012) observed increased Brassica napus oil content in crop rotation with legumes. In contrast, Rathke et al. (2006) observed that cultivating rapeseed after barley in winter significantly increased oil content as compared to that upon rotation with peas.

\section{Oil yield}

The oil yield (Figure 2C) also benefited from rotation with crotalaria, as the supply of nutrients resulted in $295 \mathrm{~kg}$ of oil $\mathrm{ha}^{-1}$. The crambe oil yield was similar to that observed by Santos et al. (2013) in tropical conditions. The results of this study are consistent with those of Aulakh and Pasricha (1998), who also found little effect of string beans on the oil content of Brassica juncea, but a significant increase in oil yield. Rathke et al. (2006) found that rapeseed, which is a winter crop, upon rotation with peas showed higher oil yield due to higher grain yield. This was also observed in the present study.

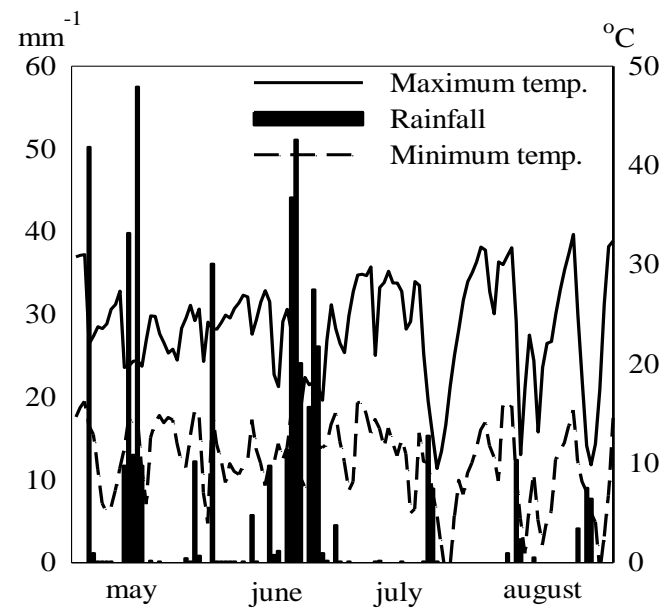

Fig 1. Maximum temperatures, minimum temperatures and rainfall during the experiment. Source: Meteorological Station of the Agronomic Institute of Paraná - IAPAR.

A correlation $(\mathrm{r}=0.92, p<0.05)$ was observed between crambe oil content and grain yield (Figure 3A). Mohammadi and Rokhzadi (2012) also observed correlation $(\mathrm{r}=0.78)$ between oil content and grain yield. The variation in oil content has genetic and biochemical limitations; thus, oil yield is further influenced by grain yield and, therefore, follows a nearly similar trend to grain yield (Premi et al., 2013), as observed in the present study $(\mathrm{r}=0.99, p<0.001)$ (Figure 3B). Rosa (2013) analyzed the potential to decompress a latosol soil with cover crops, and found that crotalaria cover crops caused significant reduction in soil density in comparison to the fallow area, although this did not influence crambe grain yield or oil content. However, the author also observed a positive linear correlation between grain yield and oil content, which confirms the results obtained in the present study. Thus, in summary, we highlight the importance of using cover crops in planting systems, especially crotalaria, for the nutrition of crambe as the main crop. The rotation between cover crops and crambe can benefit the agricultural production system, as using crambe as the main species can also improve the physical properties of the soil (Dias et al., 2015), which is a feature of Brassicas (Chen and Weil, 2011; Chen et al., 2014). Moreover, as reported by Bassegio et al. (2015b), cover crops in rotation with crambe can also increase soil fertility in the short term.

\section{Materials and Methods}

\section{Plant materials}

The crambe (Crambe abyssinica Hochst. Former. RE Fries) cultivar was FMS-Brilhante originated FMS. Cover crops used for crop rotation were Pearl millet (Pennisetum glaucum), grass brachiaria (Brachiaria brizantha), sorghum (Sorghum bicolor) and sunn hemp (Crotalaria juncea).

\section{Study site description}

The experiment was carried out in Santa Helena, Paraná State, Brazil $\left(24^{\circ} 57^{\prime} \mathrm{S}, 54^{\circ} 18^{\prime} \mathrm{W}\right.$, altitude of $\left.282 \mathrm{~m}\right)$. The 30 year mean annual temperature is $22.1^{\circ} \mathrm{C}$ with a July minimum of $16.8^{\circ} \mathrm{C}$ and a January maximum of $27.6^{\circ} \mathrm{C}$, and mean annual precipitation of $1,800 \mathrm{~mm}$. The regional climate is relatively warm and wet. Rainfall and maximum and 

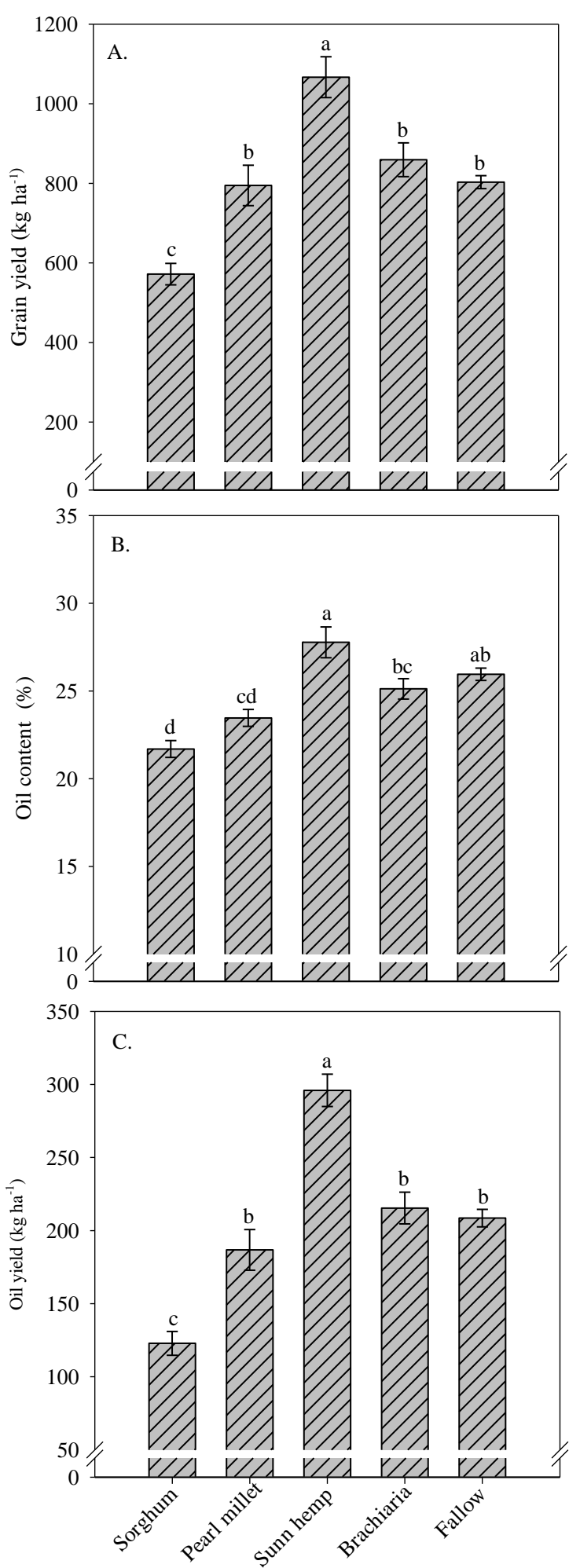

Fig 2. Grain yield (A), oil content (B) and oil yield (C) affected by cover crops. Different letters show significant differences (Tukey test, $p \leq 0.05$ ). Vertical bars show the standard error.
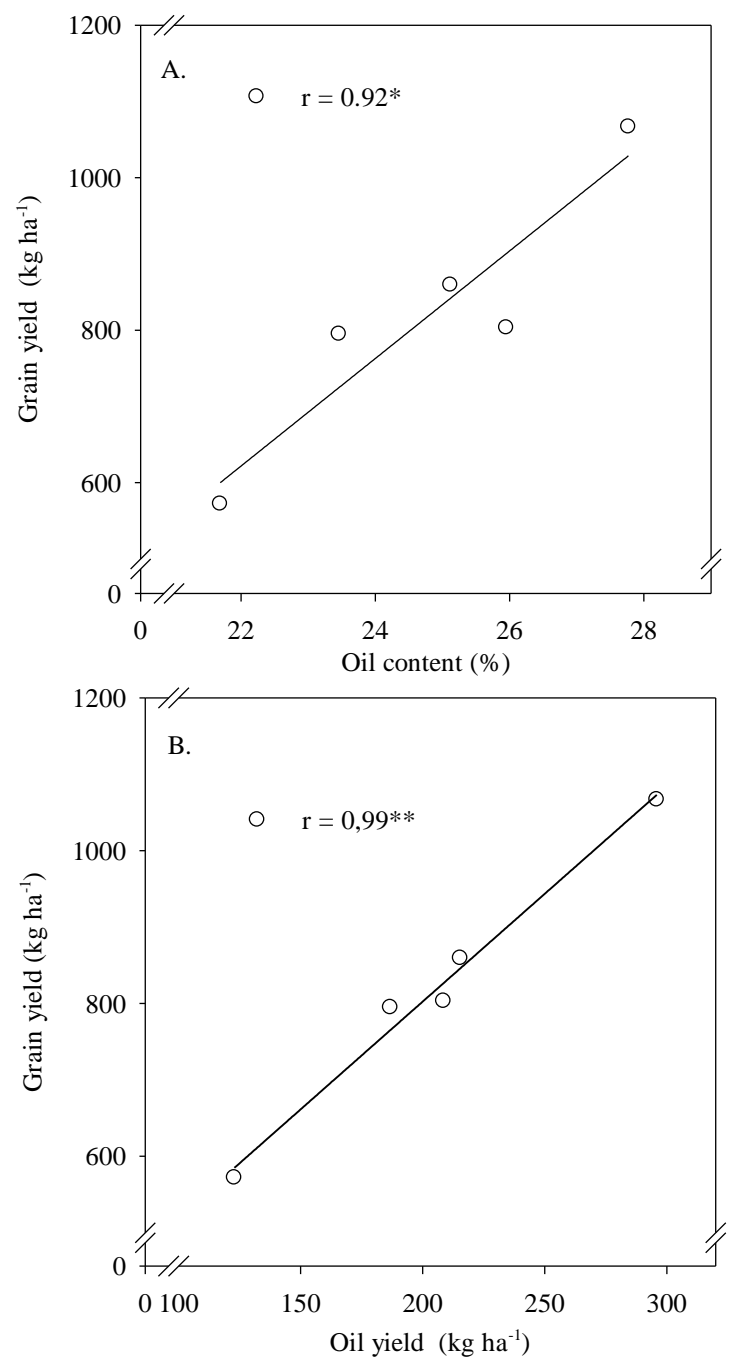

Fig 3. Correlation between oil content and grain yield (A) and oil yield and grain yield (B). *, ** significant at $5 \%(p \leq$ $0,05)$ and $1 \%(p \leq 0,01)$, respectively.

minimum temperatures recorded during the experiment are shown in Figure 1.

The soil was a Rhodic Hapludox (Soil Survey Staff, 2010), with 700,150 , and $150 \mathrm{~g} \mathrm{~kg}^{-1}$ of clay, silt and sand, respectively. Before starting the experiment, soil samples were taken from the surface layer $(0-20 \mathrm{~cm})$, air dried, sieved through a $2 \mathrm{~mm}$ mesh, and analyzed as in Embrapa (1997). Soil chemical analyses returned values of: $\mathrm{pH}$ in $\mathrm{CaCl}_{2}(0.01$ M) of $5.1 ; 14 \mathrm{~g} \mathrm{dm}^{-3}$ of organic carbon; $21 \mathrm{mg} \mathrm{dm}^{-3}$ of $\mathrm{P}$ (Mehlich-1); $0.13 \mathrm{cmol}_{\mathrm{c}} \mathrm{dm}^{-3}$ of $\mathrm{K}^{+} ; 6.07 \mathrm{cmol}_{\mathrm{c}} \mathrm{dm}^{-3}$ of $\mathrm{Ca}^{2+}$; $2.50 \mathrm{cmol}_{\mathrm{c}} \mathrm{dm}^{-3}$ of $\mathrm{Mg}^{2+} ; 12.98 \mathrm{cmol}_{\mathrm{c}} \mathrm{dm}^{-3}$ of cationic exchange capacity (CEC); and $67 \%$ of soil base saturation.

\section{Field management}

The four experimental crop rotations and fallow were initially established on February 01, 2013. Cover crops were sown in $0.45 \mathrm{~m}$ spaced rows at densities of $20,40,15$, and $20 \mathrm{~kg}$ seeds $\mathrm{ha}^{-1}$ of pearl millet, grass brachiaria, forage sorghum and sunn hemp, respectively. 
Fertilization of cover crops was carried out by applying 100 $\mathrm{kg} \mathrm{ha}^{-1}$ of 10-15-15 formulation at sowing. Seven days after the management of cover crops and spontaneous weed, in half of each experimental plot, crop residues were crushed into particles of approximately 50 to $70 \mathrm{~mm}$ long using a mechanical crusher of crop residues. Crambe was planted on May 10, 2013, in rows spaced $45 \mathrm{~cm}$ with a density of 20 seeds $\mathrm{m}^{-1}$, fertilized with 10,30 and $30 \mathrm{~kg} \mathrm{ha}^{-1}$ of $\mathrm{N}, \mathrm{P}_{2} \mathrm{O}_{5}$ and $\mathrm{K}_{2} \mathrm{O}$ respectively, and applied in the seed furrows, as recommended by Pitol (2008). A total of 20 plots, $6.4 \mathrm{~m}$ wide $\times 6.0 \mathrm{~m}$ long.

\section{Measurements}

Grain yield $\left(\mathrm{kg} \mathrm{ha}^{-1}\right)$ of crambe was determined in an area of $4.5 \mathrm{~m}^{2}$ within each plot, becoming the two central lines. Grain yield were expressed corrected to $130 \mathrm{~g} \mathrm{~kg}^{-1}$ of moisture. The oil content of grains was determined by petroleum ether extraction and the results were expresssed as percentages (IAL, 1985). Oil yield $\left(\mathrm{kg} \mathrm{ha}^{-1}\right)$ was calculated as the product of oil content and seed yield.

\section{Statistical analysis}

The experimental design consisted of randomized blocks with four replications. Original data were submitted to ANOVA and the results were compared using the Tukey's test ( $p \leq$ $0.05)$ and $\mathrm{F}$ test $(p \leq 0.05)$, respectively.

\section{Conclusion}

Oil content is influenced by cover crops. Crotalaria as predecessor species resulted in higher oil content, but the result did not differ from that obtained in the fallow area. Crambe grain and oil yield is benefited by crotalaria cover crops. Green manure was shown to be as a good option for tropical climate change and crambe adaptation. Crambe looks promising as an alternative oilseed crop for South Brazil when seeded in autumn with crotalaria cover crop in shortterm. However, it is necessary long-term studies to prove the effect of the other green manures (grasses).

\section{Acknowledgments}

To CAPES (Coordination for the Improvement of Higher Education Personnel), for financial support and providing scholarship to the first author.

\section{References}

Astier M, Maass JM, Etchevers-Barra JD, Pena JJ, Gonzalez FL (2006) Short-term green manure and tillage management effects on maize yield and soil quality in an Andisol. Soil Till Res. 88:153-159

Aulakh MS, Pasricha, NS (1998) The effect of green manuring and fertilizer $\mathrm{N}$ application on enhancing crop productivity in mustard-rice rotation in semi-arid subtropical regions. Eur J Agron. 8:51-58.

Balkcom KS, Reeves DW (2005) Sunn-hemp utilized as a legume cover crop for corn production. Agron J. 97:26-31.

Bassegio D, Santos RF, Secco D, Werncke I, Sarto MVM (2015a) Effect of cover crops and straw management on yield components of crambe. Biosci J. 31:1396-03.

Bassegio D, Santos RF, Secco D, Zanão Junior LA, Werncke I, Sarto MVM (2015b) Short-term effects of crop rotations on soil chemical properties under no-tillage condition. Aust J Crop Sci. 9:49-54.
Bitencourt R, Silva TRB, Goncalves Junior AC, Poletine JP, Dias-arieira CR, Silva CAT, Secco D, Santos RF, Alves CZ (2015) Adubação da soja usada como residual no cultivo de crambe. J Agron Sci. 4:17-30.

Bitencourt R., Silva TRB, Gonçalves Junior ACG, Poletine JP, Arieira CRD, Silva CAT, Secco D, Santos RF, Alves CZ (2016) Management of soy supply (Glycine max) and its exploitation in farming crambe (Crambe abyssinica). Afr J Agric Res. 11: 1181-1186.

Cattanêo AJ, Stangarlin JR, Bassegio D, Santos RF( 2016) Crambe affected by biological and chemical seed treatments. Bragantia. 75: 292-298.

Cheema MA, Malik MA, Hussain A, Shah SH, Basra SMA (2001) Effects of time and rate of nitrogen and phosphorus application on the growth and the seed and oil yields of canola (Brassica napus L.). J Agron Crop Sci. 186:103110.

Chen G, Weil RR (2011) Root growth and yield of maize as affected by soil compaction and cover crops. Soil Till Res. 117:17-27.

Chen G, Weil RR, Hill RL (2014) Effects of compaction and cover crops on soil least limiting water range and air permeability. Soil Till Res. 136:61-69.

Cherr CM, Scholberg JMS, McSorley R (2006) Green manure as nitrogen source for sweet corn in a warmtemperate environment. Agron J. 98:1173-1180.

Christen O (2001) Yield, yield formation and yield stability of wheat,barley and rapeseed in different crop rotations. German J Crop Sci. 5:33-39.

Crusciol CAC, Nascente AS, Mateus GP, Pariz CM, Martins PO, Borghi E (2014) Intercropping soybean and palisade grass for enhanced land use efficiency and revenue in a no till system. Eur J Agron. 58:53-62.

Dias PP, Secco D, Santos RF, Bassegio D, Santos FS, Silva PRA, Correia TP (2015) Soil compaction and drought stress on shoot and root growth in crambe (Crambe abyssinica). Aust J Crop Sci. 9:49-54.

Elfstrand S, Hedlund K, Martensson A (2007) Soil enzyme activities, microbial, yield of winter oilseed rape (Brassica napus L.). J Agron Crop Sci. 174:265-271.

Grant CA, Derksen DA, McLaren DL, Irvine RB (2011) Nitrogen fertilizer andurease inhibitor effects on canola seed quality in a one-pass seeding and fertilizing system. Field Crop Res. 121:201-208.

Hocking PJ, Randall PJ, DeMarco D (1997) The response of dryland canola to nitrogen fertilizer: partitioning and mobilization of dry matter and nitrogen, and nitrogen effects on yield components. Field Crops Res. 54:201-220.

IAL - Instituto Adolpho Lutz (1985) Chemical and physicalmethods for food analysis. Analytical Standards, São Paulo, p. 317.

Lunelli IE, Secco D, Marins AC, Rosa HA, Santos RF, Borsoi A, Veloso G, Bariccatti RA, Souza SNM, Silva TRB (2014). Effects of nutritional arrangements of NPK on the yield of grains and Crambe oil cultivation. Afr J Agric Res. 8:2048-2052.

Mauad M, Garcia RA, Vitorino ACT, Silva RMMF, Garbiate MV, Coelho LC F (2013) Dry matter and accumulation of nutrients in the shoots of crambe. Cien Rural. 43:771-778.

Mohammadi K, Rokhzad, IA (2011) An integrated fertilization system of canola (Brassica napus L.) production under different crop rotations. Ind Crops Prod. 37:264-269.

Muñoz-Carpena R, Ritter A, Bosch DD, Schaffer B, Potter TL (2008) Summer cover crop impacts on soil percolation and nitrogen leaching from a winter corn field. Agric Water Manage. 95:633-644. 
Pitol C (2008). Cultura do crambe. Tecnologia e produção: Milho safrinha e culturas de inverno 2008, Fundação MS

Premi OP, Kandpal BK, Rathore SS, Kapila Shekhawat, Chauhan JS (2013) Green manuring, mustard residue recycling and fertilizer application affects productivity and sustainability of Indian mustard (Brassica juncea L.) in Indian semi-arid tropics. Ind Crops Prod. 41: 423-429.

Rathke GW, Christen O, Diepenbrock W (2005) Effects of nitrogen source and rate on productivity and quality of winter oilseed rape (Brassica napus L.) grown in different crop rotations. Field Crops Res. 94:103-113.

Rosa HA (2013) Structuring potential cover crops in a Argiloso Latossolo and its effects on grain yield and oil crambe. (Master in Energy in Agriculture), Universidade Estadual do Oeste do Paraná, Cascavel.

Schomberg HH, Martini NL, Diaz-Perez JC, Phatak SC, Balkcom KS, Bhardwaj HL (2007) Potential for using sunn hemp as a source of biomass and nitrogen for the Piedmont and Coastal Plains regions of the southeastern USA. Agron J. 99:1448-1457.
Soil Survey Staff (2010) Keys to soil taxonomy. Natural Resources Conservation Service. 10 ${ }^{\mathrm{a}}$. ed. Washington.

Tomassoni F, Santos RF, Bassegio D, Zanao Junior LA, Secco D, Souza SNM, Nadaleti WC, Rossi E, Cremonez PA, Antonelli J (2014) Effect of soil nitrogen on crambe seeded directly over different cover crops. Int J Food Agric and Environ. 12:836-838.

Viana OH, Santos RF, Secco D, Souza SNM, Cattanêo AJ (2012) Effects of different base fertilizer levels in the development and productivity of grain and oil in the crambe culture. Acta Iguazu. 1:33-41.

Viana OH, Santos RF, Oliveira RC, Secco D, Souza SNM, Kazue TLS, Gurgacz F (2015) Crambe (Crambe abyssinica H.) development and productivity under different sowing densities. Aust J Crop Sci. 9:690-695.

Werncke I, Souza SNM, Bassegio D, Santos RF, Perreira PD, Secco D, Vidal TCM (2014) Sources and rates of nitrogen in summer corn under no-tillage on winter cover crops. Afr J Agric Res. 9:1516-1521. 